\title{
Gambaran Glukosa Darah dan Glukosa Urin pada Dewasa Muda Berat Badan Lebih dan Obes
}

\author{
Timothy D. Lengkong, ${ }^{1}$ Mayer F. Wowor, ${ }^{2}$ Siemona L. E. Berhimpon ${ }^{2}$ \\ ${ }^{1}$ Program Studi Pendidikan Dokter Fakultas Kedokteran Universitas Sam Ratulangi Manado \\ ${ }^{2}$ Bagian Patologi Klinik Fakultas Kedokteran Universitas Sam Ratulangi Manado \\ Email: timothydafid@gmail.com
}

\begin{abstract}
Increased body mass index (BMI) in overweight and obese individuals is related to blood glucose as the main source of energy. Urine glucose or glucosuria is a condition where glucose is found in the urine (usually when serum blood glucose $>200 \mathrm{mg} / \mathrm{dL}$ ). This study was aimed to obtain the profile of blood glucose and urine glucose among overweight and obese young adult individuals. This was an observational and descriptive study. Samples were taken by using non-probability sampling and consecutive sampling. The results showed that of 106 overweight and obese young adult individuals, there were 51 individuals $(48.1 \%)$ with blood glucose $<90$ $\mathrm{mg} / \mathrm{dL}$ and 55 individuals (51.9\%) with blood glucose $\geq 90 \mathrm{mg} / \mathrm{dL}$; none of them had urine glucose. In conclusion, among overweight and obese young adult individuals, about half of them had blood glucose $\geq 90 \mathrm{mg} / \mathrm{dL}$ and the others had blood glucose $\geq 90 \mathrm{mg} / \mathrm{dL}$, albeit, none had glucosuria.
\end{abstract}

Keywords: overweight, obese, blood glucose, urine glucose, BMI

\begin{abstract}
Abstrak: Peningkatan indeks massa tubuh (IMT) pada keadaan berat badan lebih dan obes berhubungan dengan glukosa darah yang merupakan sumber energi dalam tubuh. Glukosa urin atau glukosuria adalah kondisi dimana glukosa ditemukan dalam urin (biasanya saat serum glukosa darah $>200 \mathrm{mg} / \mathrm{dL}$ ). Penelitian ini bertujuan untuk mengetahui gambaran glukosa darah dan glukosa urin pada subjek dewasa muda dengan berat badan lebih dan obes. Jenis penelitian ialah deskriptif observasional dengan pengambilan sampel menggunakan non-probability sampling jenis consecutive sampling. Hasil penelitian mendapatkan dari 106 dewasa muda yang tergolong berat badan lebih dan obes, terdapat 51 orang $(48,1 \%)$ yang memiliki kadar glukosa darah $<90 \mathrm{mg} / \mathrm{dL}$ dan 55 orang $(51,9 \%)$ yang memiliki kadar glukosa darah $\geq 90 \mathrm{mg} / \mathrm{dL}$, serta tidak ada yang memiliki glukosa urin. Simpulan penelitian ini ialah pada dewasa muda yang tergolong berat badan lebih dan obes, sekitar setengah daripadanya memiliki kadar glukosa darah $\geq 90 \mathrm{mg} / \mathrm{dL}$ dan setengahnya lagi memiliki kadar glukosa darah $\geq 90 \mathrm{mg} / \mathrm{dL}$, tetapi tidak ada yang memiliki glukosuria.
\end{abstract}

Kata kunci: berat badan lebih, obes, glukosa darah, glukosa urin, IMT

\section{PENDAHULUAN}

Berat badan lebih (overweight) dan obes (obesitas) merupakan suatu keadaan akumulasi lemak abnormal atau berlebih yang berpotensi mengganggu kesehatan. Status gizi ini dapat ditentukan dengan menggunakan rumus indeks massa tubuh (IMT), yaitu berat badan seseorang dalam satuan kilogram $(\mathrm{Kg})$ dibagi dengan kuadrat tinggi badannya dalam satuan meter $(\mathrm{m})$. Penyebab mendasar dari berat badan lebih dan obes ialah ketidakseimbangan energi antara kalori yang dikonsumsi dan kalori yang dikeluarkan. ${ }^{1}$

Data hasil utama Riset Kesehatan Dasar (Riskesdas) 2018 menunjukkan bahwa prevalensi proporsi berat badan lebih pada dewasa $>18$ tahun di Indonesia pada tahun 2013 sebesar 11,5\% dan pada tahun 2018 sebesar 13,6\%. Prevalensi proporsi obes pada dewasa $>18$ tahun di Indonesia pada tahun 2013 sebesar 14,8\% dan pada tahun 
2018 sebesar 21,8\%. Proporsi obes pada dewasa berusia $>18$ tahun di Indonesia pada tahun 2018 sebesar 21,8\% dan Provinsi Sulawesi Utara yang paling tinggi dengan prevalensi $30,2 \%{ }^{2}$

Keadaan berat badan lebih dan obes berhubungan erat dengan kadar glukosa darah. Penumpukan jaringan lemak pada berat badan lebih dan obes dapat menyebabkan terjadinya resistensi insulin sehingga memicu peningkatan kadar glukosa darah dalam tubuh. ${ }^{3}$ Bila kadar glukosa dalam darah meningkat dan tidak dapat direabsorpsi di ginjal, maka terjadi ekskresi glukosa dalam urin atau glukosuria yaitu ditemukannya glukosa dalam urin. ${ }^{4}$

Pemeriksaan glukosa darah pada dasarnya bertujuan untuk mendiagnosis penyakit diabetes melitus (DM). Pemeriksaan glukosa darah yang dianjurkan yaitu pemeriksaan glukosa secara enzimatik dengan bahan plasma darah vena. Pemantauan kadar glukosa darah juga dapat dilakukan dengan menggunakan pemeriksaan glukosa darah kapiler dengan glukometer. Diagnosis DM tidak dapat ditegakkan atas ditemukannya glukosa urin (glukosuria). ${ }^{5}$ Pemeriksaan glukosa urin sangat berkaitan dengan urinalisis (parameter pemeriksaan urin) yang bertujuan untuk memberikan indikasi kondisi ginjal dan kondisi sistemik seseorang. Salah satu pemeriksaan urin yang biasa dilakukan, antara lain metode dipstick (carik celup). Pemeriksaan urin yang biasa dilakukan dengan dipstick antara lain untuk menilai: berat jenis, $\mathrm{pH}$, glukosa, protein, keton, darah, bilirubin, urobilinogen, nitrit, dan leukosit esterase. Metode dipstick pada pemeriksaan glukosa urin cukup akurat karena memiliki nilai sensitivitas dan spesifitas yang tinggi. ${ }^{6}$

Secara global, sekitar 38,9\% dewasa muda berusia 18-24 tahun memiliki prevalensi berat badan lebih dan obes yang sangat tinggi. ${ }^{7}$ Sehubungan dengan kejadian peningkatan glukosa darah dan munculnya glukosa urin pada individu dengan berat badan lebih dan obes, maka penulis tertarik untuk mendapatkan gambaran glukosa darah dan glukosa urin pada subjek dewasa muda berat badan lebih dan obes.

\section{METODE PENELITIAN}

Penelitian ini dilaksanakan pada bulan Agustus 2019-Desember 2019 di Fakultas Kedokteran Universitas Sam Ratulangi Manado. Jenis penelitian ini ialah deskriptif observasional. Sampel penelitian ialah sampel glukosa darah sewaktu (GDS) kapiler dan urin sewaktu dari semua mahasiswa Fakultas Kedokteran Universitas Sam Ratulangi Manado yang memenuhi kriteria penelitian. Populasi penelitian ialah setiap individu dengan status mahasiwa Program Studi Pendidikan Dokter Fakultas Kedokteran Universitas Sam Ratulangi Manado angkatan 2019-2016.

Alat-alat yang digunakan ialah wadah penampung urin, spidol, sarung tangan, tisu basah, tisu kering, dipstick, standar pembanding, kapas alkohol, glukosameter, lanset, strip gula darah, dan wadah limbah. Bahan-bahan yang digunakan ialah sampel gula darah sewaktu (darah kapiler) dan sampel urin sewaktu. Data yang diperoleh dikumpulkan dan diolah dalam bentuk tabel yang menggunakan program IBM SPSS Statistics 26.

\section{HASIL PENELITIAN}

Penelitian ini dilakukan terhadap mahasiswa Fakultas Kedokteran Universitas Sam Ratulangi dengan rentang usia 18-24 tahun yang sesuai dengan kriteria inklusi penelitian. Sampel yang diambil ialah glukosa darah sewaktu dan urin sewaktu dan jumlah sampel yang diperoleh sebanyak 106 sampel.

Tabel 1 memperlihatkan gambaran distribusi subyek berdasarkan klasifikasi IMT dengan hasil 44 subyek dengan berat badan lebih, 44 subyek obes I, 18 subyek obes II . Berdasarkan jenis kelamin didapatkan subyek berjenis kelamin perempuan $(66 \%)$ lebih banyak daripada laki-laki (34\%).

Tabel 2 memperlihatkan gambaran distribusi subyek berdasarkan kadar GDS. Kadar glukosa darah $<90 \mathrm{mg} / \mathrm{dL}$ pada subyek berat badan lebih hampir sama banyak dengan subyek obes (20 vs 23 subyek) tetapi berbeda jauh dengan subyek obes II ( 8 subyek). Kadar glukosa darah $\geq 90$ $\mathrm{mg} / \mathrm{dL}$ pada subyek berat badan lebih 
hampir sama banyak dengan subyek obes (24 vs 21 subyek) tetapi berbeda jauh dengan subyek obes II (10 subyek). Persentase subyek dengan glukosa darah $<90$ $\mathrm{mg} / \mathrm{dL}(48,1 \%)$ lebih rendah daripada subyek dengan glukosa darah $\geq 90 \mathrm{mg} / \mathrm{dL}$ $(51,9 \%)$.

Tabel 3 memperlihatkan gambaran distribusi subyek berdasarkan kadar GDS sebagai penyaring diagnosis diabetes melitus (DM). Pada kelompok berat badan lebih, 18,9\% subyek bukan DM dan 22,6\% subyek belum pasti DM. Pada kelompok obes I, 21,7\% subyek bukan DM dan 19,8\% subyek belum pasti DM. Pada kelompok obes II, 8 subyek $(7,5 \%)$ bukan DM dan 10 subyek $(9,4 \%)$ belum pasti DM. Tidak terdapat subyek $(0 \%)$ yang berada pada kategori DM.

Tabel 4 memperlihatkan gambaran distribusi glukosa urin. Semua subyek (100\%) baik pada kelompok berat badan lebih, kelompok obes I, maupuan kelompok obes II, memiliki kadar glukosa urin normal (negatif).

Tabel 1. Distribusi IMT berdasarkan jenis kelamin

\begin{tabular}{ccccc}
\hline $\begin{array}{c}\text { Jenis } \\
\text { kelamin }\end{array}$ & $\begin{array}{c}\text { Berat badan } \\
\text { lebih }\end{array}$ & Obes I & Obes II & Persentase \\
\hline Laki-laki & 10 & 17 & 9 & 34 \\
Perempuan & 34 & 27 & 9 & 66 \\
Total & 44 & 44 & 18 & 100 \\
\hline
\end{tabular}

Tabel 2. Distribusi kadar glukosa darah sewaktu

\begin{tabular}{ccccc}
\hline $\begin{array}{c}\text { Glukosa } \\
\text { darah }\end{array}$ & $\begin{array}{c}\text { Berat badan } \\
\text { lebih }\end{array}$ & Obes I & Obes II & Persentase \\
\hline$<90 \mathrm{mg} / \mathrm{dL}$ & 20 & 23 & 8 & 48,1 \\
$\geq 90 \mathrm{mg} / \mathrm{dL}$ & 24 & 21 & 10 & 51,9 \\
Total & 44 & 44 & 18 & 100 \\
\hline
\end{tabular}

Tabel 3. Distribusi kadar glukosa darah sewaktu untuk diagnose diabetes melitus (DM)

\begin{tabular}{ccccc}
\hline Glukosa darah & $\begin{array}{c}\text { Berat badan } \\
\text { lebih }\end{array}$ & Obes I & Obes II & Persentase \\
\hline $\begin{array}{c}\text { Bukan DM } \\
(<90 \mathrm{mg} / \mathrm{dL})\end{array}$ & 20 & 23 & 8 & 48,1 \\
Belum pasti DM & 24 & 21 & 10 & 51,9 \\
$\left(\begin{array}{c}(0-199 \mathrm{mg} / \mathrm{dL}) \\
\mathrm{DM}\end{array}\right.$ & 0 & 0 & 0 & 0 \\
$(\geq 200 \mathrm{mg} / \mathrm{dL})$ & 44 & 44 & 18 & 100 \\
\hline Total & & & & \\
\hline
\end{tabular}

Tabel 4. Distribusi kadar glukosa urin

\begin{tabular}{ccccc}
\hline $\begin{array}{c}\text { Glukosa } \\
\text { urin }\end{array}$ & $\begin{array}{c}\text { Berat badan } \\
\text { lebih }\end{array}$ & Obes I & Obes II & Persentase \\
\hline- & 44 & 44 & 18 & 100 \\
+- & 0 & 0 & 0 & 0 \\
+ & 0 & 0 & 0 & 0 \\
++ & 0 & 0 & 0 & 0 \\
+++ & 0 & 0 & 0 & 0 \\
++++ & 0 & 0 & 0 & 0 \\
Total & 44 & 44 & 18 & 100 \\
\hline
\end{tabular}




\section{BAHASAN}

Pada penelitian ini didapatkan 106 responden penelitian berusia 18-24 tahun dengan berat badan lebih dan obes yang memenuhi kriteria inklusi. Kelompok berat badan lebih dan kelompok obes I memiliki frekuensi dan persentase yang sama yaitu 44 responden $(42 \%)$ serta 18 responden $(17 \%)$ lainnya terdapat pada kelompok obes II. Dengan demikian kelompok obesitas (obes I dan obes II) lebih banyak daripada kelompok berat badan lebih (Tabel 1). Hal ini sejalan penelitian Novitasary ${ }^{8}$ yang menyatakan bahwa kejadian obes sangat tinggi di Provinsi Sulawesi Utara $(37,1 \%)$ dengan prevalensi pada perempuan lebih tinggi daripada laki-laki.

Hasil penelitian ini mendapatkan bahwa kadar glukosa darah sewaktu (GDS) dalam rentang $<90 \mathrm{mg} / \mathrm{dL}$ yaitu $48,1 \%$ dan kadar glukosa darah sewaktu dalam rentang $\geq 90$ $\mathrm{mg} / \mathrm{dL}$ yaitu $51,9 \%$ (Tabel 2). Berat badan lebih dan obes memiliki hubungan bermakna dengan kadar GDS. Penelitian oleh Amir ${ }^{9}$ menyatakan bahwa peningkatan kadar glukosa darah dalam tubuh terjadi seiring peningkatan IMT. Pada penelitian ini kadar GDS terlihat cenderung meningkat pada keadaan berat badan lebih dan obes.

Hasil penelitian ini mendapatkan bahwa jumlah responden terbanyak pada kategori belum pasti DM (90-199 mg/dL) yaitu 55 responden $(51,9 \%)$ dengan kelompok obes yang mendominasinya (Tabel 3). Peningkatan glukosa darah dipengaruhi oleh faktor IMT. Hal ini selaras dengan penelitian Polii et $\mathrm{al}^{10}$ yang menyatakan pada keadaan obesitas terjadi penurunan adiponektin dan peningkatan asam lemak bebas yang tidak berlangsung sesuai kerja insulin sehingga terjadilah sensitifitas insulin dan berakhir pada resistensi insulin. Asam lemak dan beberapa metabolit dalam tubuh mengaktifkan protein kinase dan merusak sinyal insulin dengan menaikkan fosforilasi serin yang bersifat inhibisi dari insulin receptor substrate (IRS), sehingga menyebabkan resistensi insulin. Hal ini menyebabkan terjadinya penurunan penggunaan glukosa disertai peningkatan produksi glukosa sehingga berakibat peningkatan kadar glukosa dalam darah.

Pada penelitian ini didapatkan bahwa seluruh responden $(100 \%)$ memiliki kadar glukosa urin yang normal (negatif) (Tabel 4). Hal ini dapat disebabkan karena tidak ada responden yang memiliki glukosa darah berlebih atau bahkan masuk dalam kategori diabetes melitus sehingga tubulus proksimal ginjal tidak memroduksi glukosa yang akan diekskresi di dalam urin. Hal ini sejalan dengan penelitian oleh Lindo ${ }^{11}$ yang menyatakan bahwa pada keadaan berat badan lebih atau obes dengan kadar glukosa darah masih normal maka tidak akan terjadi sekresi glukosa dalam urin atau glukosuria. Glukosuria adalah kondisi dimana glukosa ditemukan dalam urin. ${ }^{12}$ Ekskresi glukosa dalam urin terjadi pada keadaan glukosa dalam darah meningkat sehingga melampaui kemampuan reabsorpi tubuli ginjal. ${ }^{13}$

\section{SIMPULAN}

Pada dewasa muda berusia 18-24 tahun yang tergolong berat badan lebih dan obes didapatkan $48,1 \%$ memiliki kadar glukosa darah $<90 \mathrm{mg} / \mathrm{dL}$ dan $51,9 \%$ memiliki kadar glukosa darah $\geq 90 \mathrm{mg} / \mathrm{dL}$ tetapi tidak ada yang memiliki glukosuria.

\section{Konflik Kepentingan}

Penulis menyatakan tidak terdapat konflik kepentingan dalam studi ini.

\section{DAFTAR PUSTAKA}

1. World Health Organization. who.int. Obesity and overweight [Online]. 2018 [cited 2019 Dec 5]. Available from: https: //www.who.int/news-room/factsheets/detail/obesity-and-overweight.

2. Kesehatan KKBPdP. depkes. Hasil Utama Riskesdas 2018 [Online]. 2018 [citied 2019 Sep 12. Available from: www. depkes.go.id/resources/download/infoterkini/materi_rakorpop_2018/Hasil\%2 0Riskesdas\%202018.pdf?opwvc=1

3. Auliya P, Oenzil F, Rofinda ZD. Gambaran Kadar Gula Darah pada Mahasiswa Fakultas Kedokteran Universitas Andalas yang memiliki berat badan berlebih dan obesitas. Jurnal Kesehatan Andalas. 2016;5(3):528-32.

4. Welliangan M, Wowor M, Mongan A. Gam- 
60 Medical Scope Journal (MSJ), Volume 1, Nomor 2, Januari-Juni 2020, hlm.56-60

baran kadar glukosa urin pada primagravida dengan orang tua penyandang diabetes melitus di Kota Manado. eBiomedik. 2019;7(1):19-23.

5. Rudijanto A, Yuwono A, Shahab A, Manaf A, Pramono B, et al. Konsesus Pengelolaan dan Pencegahan Diabetes Melitus Tipe 2 di Indonesia 2015 (1st ed). Jakarta: PB PERKENI, 2015.

6. KS I, Puspito L. Akurasi pemeriksaan carik celup pada urinalisis proteinuria dan glukosuria dibandingkan dengan metoda standard. Molluca Medica. 2012; 5(1):19.

7. Partridge SR, Redfern J. Obesity prevention in young people: the role of technology in primary care. Journal of Primary Health Care and General Practice. 2018;2(1):1.

8. Novitasary MD, Mayulu N, Kawengian S. Hubungan antara aktivitas fisik dengan obesitas pada wanita usia subur peserta jamkesmas di Puskesmas Wawonasa
Kecamatan Singkil Manado. eBiomedik. 2013;1(2):1040-6.

9. Amir S, Wungouw H, Pangemanan D. Kadar glukosa darah sewaktu pada pasien diabetes melitus tipe 2 di Puskesmas Bahu Kota Manado. eBiomedik. 2015; 3(1):32-40.

10. Polii R, Kepel B, Bodhi W, Manampiring A. Hubungan kadar glukosa darah puasa dengan obesitas pada remaja di Kecamatan Bolangitang Barat Kabupaten Bolaang Mongondow Utara. eBiomedik. 2016;4(2).

11. Lindo C, Rompis J, Pateda V. Perbandingan glukosuri pada remaja obes dengan yang tidak obes. e-CliniC. 2015;3(1):253.

12. Wilson D. McGraw-Hill's Manual of Laboratory Diagnostic Tests. Illionis: McGraw Hill Education, 2008; p. 588-9.

13. Sherwood L. Human Physiology from Cells to Systems (9th ed). Canada: Cengange Learning, 2014; p. 496-512. 